\title{
Kecukupan Pasteurisasi Sistem Kontinyu Krimer Kental Manis dan Pengaruhnya Terhadap Stabilitas Selama Penyimpanan
}

\section{Thermal Adequacy of Continuously Pasteurized Sweetened Condensed Creamer and its Effect on Product Stability during Storage}

\author{
Anis Zamaluddien' ${ }^{1}$, Feri Kusnandar ${ }^{2,3)^{*}}$, Eko Hari Purnomo ${ }^{2,3)}$ \\ 1) Program Studi Magister Teknologi Pangan, Sekolah Pascasarjana, Institut Pertanian Bogor, Bogor \\ 2) Departemen Ilmu dan Teknologi Pangan, Fakultas Teknologi Pertanian, Institut Pertanian Bogor, Bogor \\ ${ }^{3)}$ Southeast Asian Food and Agricultural Science and Technology Center, LPPM, Institut Pertanian Bogor, Bogor
}

\begin{abstract}
A sweetened condensed creamer (SCC) is a well-known dairy-based product used in various food products. SCC has $\mathrm{pH}$ of 6.00 and water activity $\left(a_{w}\right)$ of less than 0.8. A pasteurization process is applied in SCC processing to inactivate potential pathogenic microorganism in order to yield safely consumed product with a long shelf-life. The aim of this study was to evaluate thermal process adequacy of SCC in a commercial scale continuous pasteurization at $85^{\circ} \mathrm{C}$ and $95^{\circ} \mathrm{C}$. Thermal process adequacy was determined by comparing the pasteurization value $(P)$ of the process with standardized $P$ value at different $D$ cycles $(2 D, 3 D$, and $6 D)$ of targeted microorganism and lipase enzyme. Pasteurization process at both $85^{\circ} \mathrm{C}$ and $95^{\circ} \mathrm{C}$ satisfactorily inactivated targeted microorganism (vegetative cells, coliform, yeast and mould, Salmonella, S aureus, and L monocytogenes). However, the designed pasteurization did not sufficiently inactivate lipase enzyme. SCC processed at $85^{\circ} \mathrm{C}$ had a longer shelf-life in term of its viscosity (292.4 days) than that of pasteurized at $95^{\circ} \mathrm{C}$ (174.5 days).
\end{abstract}

Keywords: pasteurization value, rheology, shelf-life, sweetened condensed creamer, thermal process

\begin{abstract}
Abstrak. Krimer kental manis (KKM) merupakan produk olahan susu yang dikenal di Indonesia untuk berbagai aplikasi dalam produk pangan. KKM memilki pH sekitar 6.00 dan aktifitas air aktivitas air $\left(\mathrm{a}_{\mathrm{w}}\right)$ kurang dari 0.8. Dengan karakteristik tersebut, proses pasteurisasi dapat diterapkan untuk membunuh mikroba patogen pada proses pembuatannya. Penelitian ini bertujuan untuk mengevaluasi kecukupan proses pasteurisasi dalam skala komersial pada suhu pasteurisasi $85^{\circ} \mathrm{C}$ and $95^{\circ} \mathrm{C}$. Kecukupan proses pasteurisasi dilakukan dengan membandingkan nilai pasteurisasi pada kedua suhu dengan nilai pasteurisasi standar pada berbagai siklus $\mathrm{D}(2 \mathrm{D}, 3 \mathrm{D}$, dan $6 \mathrm{D})$ dari mikroorganisme target dan enzim lipase. Proses pasteurisasi pada kedua suhu $85^{\circ} \mathrm{C}$ and $95^{\circ} \mathrm{C}$ mencukupi untuk menginaktivasi sel vegetatif, kapang, khamir, Staphilococcus aureus, Salmonella, dan Lysteria Monocytogenes, namun tidak mencukupi untuk menginaktivasi enzim lipase. Berdasarkan parameter viskositas, umur simpan KKM yang yang diproses pada suhu pasteurisasi $85^{\circ} \mathrm{C}$ adalah 292.4 hari yang lebih lama dengan yang diproses pada suhu $95^{\circ} \mathrm{C}(174.5$ hari).
\end{abstract}

Kata Kunci: krimer kental manis, nilai pasteurisasi, proses termal, reologi, umur simpan

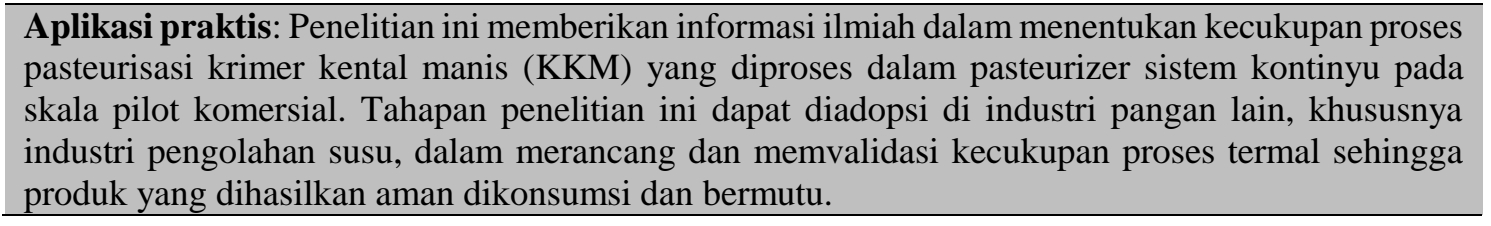

\section{PENDAHULUAN}

Konsumsi susu dan produk turunannya di Indonesia mengalami pertumbuhan, salah satunya adalah krimer kental manis (KKM). KKM banyak digunakan untuk memasak, campuran teh dan kopi, atau diminum langsung setelah dilarutkan, dan sebagai bahan baku industri seperti permen dan coklat bar (Nieuwenhuijse 2011). Rata-rata pertumbuhan konsumsi KKM selama periode 2013-2017 adalah 11.19\% (Kementan 2017) Dengan kecenderungan pertumbuhan tersebut, industri pengolahan susu meningkatkan produksi KKM yang memiliki mutu yang baik dan aman dikonsumsi agar produknya menjadi pilihan konsumen.

Berdasarkan kategori pangan (BPOM 2015), KKM memiliki kode 01.3.1 yang didefinisikan sebagai produk susu berbentuk cairan kental, yang diperoleh dari susu yang telah ditambahkan gula dan lemak nabati yang 
kemudian sebagian airnya dihilangkan hingga mencapai kepekatan tertentu, atau merupakan hasil rekonstitusi susu bubuk dengan penambahan gula dan lemak nabati/minyak nabati dan bahan lain. Produk dipasteurisasi dan dikemas secara kedap (hermetis). Codex-Stan No 282-1971 (Codex 2011) mensyaratkan kandungan lemak susu minimum $8 \%$, padatan susu $28 \%$, dan padatan non-lemak 34\% dalam KKM, namun Indonesia belum mensyaratkannya. KKM komersial mengandung lemak sekitar $10.13 \%$, total padatan $72 \%$ dan sukrosa $47.63 \%$.

KKM berbentuk cairan pekat yang memiliki pH 5.96.1 dan aktivitas air $\left(\mathrm{a}_{\mathrm{w}}\right)$ kurang dari 0.80. Nilai $\mathrm{a}_{\mathrm{w}}$ yang rendah dari KKM disebabkan oleh proses pemekatan (evaporasi) dan kandungan gula yang tinggi. Oleh karena itu, gula yang ditambahkan bukan hanya berfungsi sebagai pemanis, tetapi juga menghambat kerusakan produk dengan mencegah pertumbuhan mikroba, terutama bakteri patogen. Walaupun pH dari KKM di atas 4.6 yang memungkinkan Clostridium botulinum tumbuh, namun dengan nilai $\mathrm{a}_{\mathrm{w}}$ kurang dari 0.85 , maka pertumbuhan mikroba tersebut dapat dihambat. Brocklehurst et al. (1995) melaporkan bahwa pada konsentrasi sukrosa 45\%, pertumbuhan Salmonella typhimurium LT2 juga dapat dihambat. Madriz (2003) menyatakan bahwa gula menyebabkan berpindahnya air dari dalam ke luar sel bakteri melalui osmosis yang menyebabkan plasmolisis dan menghambat perkembangan mikroba tersebut.

Produk pangan yang memiliki $\mathrm{pH}$ lebih dari 4.6 dan $\mathrm{a}_{\mathrm{w}}$ kurang dari 0.85 lebih mudah ditumbuhi mikroba dari kelompok kapang, khamir dan beberapa bakteri yang tidak tahan panas (Hariyadi 2017). Produk yang memiliki $\mathrm{pH}$ dan $\mathrm{a}_{\mathrm{w}}$ tersebut dapat diawetkan dengan proses pasteurisasi dengan membunuh mikroba target sehingga produk tersebut aman dikonsumsi, namun mutu produk masih dapat dipertahankan. Proses pasteurisasi susu juga dapat menginaktivasi enzim lipase (Hudson et al. 2003; Vervoort et al. 2011). Selain itu, pasteurisasi juga dapat meminimalkan kerusakan mutu organoleptik dan memperpanjang umur simpan produk (Silva dan Gibs 2010; Shah et al. 2017).

Pasteurisasi merupakan tahapan dalam proses produksi KKM yang bertujuan untuk mengurangi jumlah mikroba, khususnya mikroba patogen dan pembusuk. Di antara mikroba yang menjadi target proses pasteurisasi dalam produksi KKM adalah Staphylococcus aureus. BPOM (2016) mensyaratkan KKM dengan batas maksimum kandungan Staphylococcus aureus $\left(10^{2} \mathrm{koloni} / \mathrm{mL}\right)$, kapang dan khamir (10 koloni/mL). Dalam praktek di industri pengolahan susu, mikroba lain seperti angka lempeng total, Salmonella, dan Lysteria monocytogenes digunakan sebagai parameter keamanan sebelum produk didistribusikan.

Proses pasteurisasi yang dilakukan oleh industri KKM umumnya menerapkan pasteurisasi sistem kontinyu, yaitu berlangsung sebelum produk dikemas di bagian holding tube. Proses pasteurisasi dilakukan dalam waktu singkat pada suhu di bawah $100^{\circ} \mathrm{C}$. Setelah proses pasteurisasi, produk masih mengalami proses penguapan, penambahan laktosa dan ageing sebelum dilakukan pengemasan. Adanya proses penguapan setelah proses pasteurisasi dan kandungan gula yang tinggi menurunkan $\mathrm{a}_{\mathrm{w}}$ KKM di bawah 0.85, sehingga pengawetan KKM bukan hanya disebabkan oleh proses pasteurisasi, tetapi juga oleh adanya penurunan $\mathrm{a}_{\mathrm{w}}$.

Kecukupan panas proses pasteurisasi dalam sistem kontinyu ditentukan oleh sifat reologi bahan (viskositas dan sifat aliran bahan yang masuk ke dalam holding tube), dan kinerja mesin (holding temperature, laju alir bahan, panjang pipa, dan diameter pipa) (Heldman dan Singh 2009). Proses pasteurisasi yang diterapkan harus menjamin mikroba target yang dipersyaratkan telah dibunuh. Evaluasi kecukupan proses pasteurisasi pada skala industri telah dilakukan oleh Hafzialman et al. (2014) untuk produk nata de coco, namun dilakukan pada sistem batch. Kecukupan proses pasteurisasi bahan cair dalam sistem kontinyu dihitung berdasarkan pada partikel yang paling cepat bergerak yang dinyatakan sebagai kecepatan maksimum atau $\mathrm{v}_{\max }$ (Tomasula dan Kozempel 2004). Pemilihan kombinasi suhu dan waktu proses pasteurisasi juga mempengaruhi umur simpan dari produk yang dihasilkan (Vegara et al. 2013; Sobral et al. 2016).

Beberapa penelitian tentang produk KKM yang telah dilaporkan terkait dengan mutu produk (Asaduzzaman 2007; Pereira et al. 2017), formulasi KKM dengan bahan baru dan stabilitasnya selama penyimpanan (Saragih 2011). Namun, belum ada penelitian untuk mengevaluasi kecukupan proses pasteurisasi KKM dalam sistem kontinyu dan pengaruhnya terhadap stabilitas produk selama penyimpanan yang menjadi fokus dari penelitian ini.

\section{BAHAN DAN METODE}

\section{Bahan dan alat}

Bahan yang digunakan adalah KKM yang dibuat dengan mencampurkan air, susu segar, gula, maltodekstrin, skim milk powder, sweet whey powder, minyak sawit, penstabil dan vitamin. Susu yang digunakan mengandung total padatan $11 \%$. KKM yang dihasilkan memiliki pH 6.0, sukrosa $45 \%$, total padatan $69 \%$, dan berat jenis $1.240-1.262 \mathrm{~g} / \mathrm{mL}$.

Penelitian dilakukan di suatu industri pengolahan susu di Indonesia. Alat utama yang digunakan dalam penelitian ini adalah mesin pengolahan KKM pada skala komersial yang terdiri dari mesin mixer, homogenizer, pasteurizer, flash cooler, storage tank, dan filler. Kapasitas produksi KKM untuk setiap batch adalah $6700 \mathrm{~kg}$. Proses pasteurisasi dilakukan pada mesin pasteurizer APV Baker seri N35 dengan kapasitas $5 \mathrm{~m}^{3} / \mathrm{jam}$ yang dipasang holding tube jenis sanitary pipe 2.5 in (inside diameter $0.06019 \mathrm{~m}$ ) dengan panjang pipa $22.45 \mathrm{~m}$. Peratalan analisis yang digunakan di antaranya adalah pH-meter (Methrom, seri 780), viskometer (Brookfield, Seri DV3TVTJ0), hidrometer, Near Infra Red (NIR Bruker seri MPA), dan alat kromameter (Lovibond, seri RT 100). 


\section{Proses pembuatan KKM}

Proses pembuatan KKM diawali dengan mencampur bahan-bahan, yaitu air, susu segar, gula, maltodekstrin, skim milk powder, sweet whey powder, minyak sawit, penstabil dan vitamin. Bahan yang sudah dicampur kemudian dipasteurisasi dalam sistem kontinyu yang merupakan proses utama dalam penelitian ini. Pasteurisasi dilakukan pada dua suhu yang berbeda, yaitu $85^{\circ} \mathrm{C}$ dan $95^{\circ} \mathrm{C}$, dengan holding time 30 detik untuk kedua suhu tersebut. Setelah proses pasteurisasi, dilakukan proses penguapan dan penambahan kristal laktosa. Proses berikutnya adalah ageing dalam waktu 1-2 jam sebelum dilakukan pengisian ke dalam kemasan kaleng dengan tinggi $8 \mathrm{~cm}$ dan diameter $7 \mathrm{~cm}$. Sampel sebelum dan setelah proses pasteurisasi dianalisis total padatan, analisis mikrobiologi, densitas, viskositas, indeks tingkah laku aliran (n) dan indeks konsistensi (K).

\section{Analisis fisikokimia}

Analisis kimia KKM meliputi kadar lemak, protein, sukrosa, dan total padatan menggunakan alat Near Infra Red (NIR Bruker), sedangkan analisis fisik mencakup densitas (menggunakan hydrometer) dan $\mathrm{pH}$ (menggunakan $\mathrm{pH}$-meter). Hasil analisis fisikokimia KKM dibandingkan dengan persyaratan yang diatur dalam Kategori Pangan kode 01.3.1 (BPOM 2015).

\section{Analisis mikrobiologi}

Analisis mikrobiologi mencakup angka lempeng total (metode SNI 2987:2008), koliform (metode BS ISO 4832:2006), kapang khamir (metode SNI 19-2897:1992), Staphilococcus aureus (metode SNI ISO 6888:2012), dan Salmonella (metode SNI ISO 6579:2015). Hasil uji mikrobiologi ini dibandingkan dengan persyaratan batas maksimum mikrobiologi pangan olahan yang diatur dalam Perka BPOM Nomor 16 Tahun 2016 (BPOM 2016).

\section{Analisis sifat reologi}

Viskositas. Sebanyak $500 \mathrm{~mL}$ sampel susu yang telah diformulasi dimasukkan ke dalam beaker glass dan diukur viskositasnya dengan menggunakan Brookfiled viscometer LV2 pada kecepatan rotasi $40 \mathrm{rpm}$ dengan spindle berbentuk silinder (panjang $(\mathrm{L})=0.684 \mathrm{~cm}$; jarijari $(\mathrm{R})=0.9345 \mathrm{~cm}$. Viskositas yang terukur merupakan apparent viscosity $\left(\mu_{\mathrm{a}}\right)$ dan dinyatakan dalam satuan $\mathrm{cP}$.

Nilai $\boldsymbol{n}$ dan K. Sebanyak $500 \mathrm{~mL}$ sampel yang diukur sebagai hubungan shear rate $(\gamma)$ dan shear stress-nya $(\tau)$ dengan Brookfiled viscometer LV2. Shear rate divariasikan dengan mengatur kecepatan rotasi (N), 20, 30, 40, 50, 60, dan $70 \mathrm{rpm}$, sedangkan shear stress berdasarkan nilai torque (A, \%) pada kecepatan rotasi yang bersesuaian. Shear rate $(\gamma, 1 /$ detik) dihitung dengan menggunakan persamaan (1), sedang shear stress $\left(\tau, \mathrm{N} / \mathrm{m}^{2}\right)$ dihitung dengan persamaan dan (2). Jarak antara dinding silinder dengan dinding wadah pengukuran $(\sigma)$ adalah $3.815 \mathrm{~cm}$.

Shear rate $(\gamma)=\frac{2 \pi \mathrm{RN}}{\sigma}$
Shear stress $(\tau)=\frac{\mathrm{A}}{2 \pi \mathrm{r}^{2} \mathrm{~L}}$

Dengan menggunakan persamaan power law, maka nilai $\mathrm{n}$ dan $\mathrm{K}$ dapat ditentukan dengan persamaan (3). Nilai $\mathrm{n}$ digunakan untuk mengelompokkan sifat bahan apakah bersifat Newtonian atau non-Newtonian (pseudoplastik bila $\mathrm{n}<1$ atau dilatan bila $\mathrm{n}>1$ ). Nilai $\mathrm{n}$ menunjukkan index tingkah laku aliran (tanpa satuan), sedangkan $\mathrm{K}$ menunjukkan koefisien kekentalan (dyne $\operatorname{detik} / \mathrm{cm}^{2}$ ).

$\tau=\mathrm{K}(\Upsilon)^{\mathrm{n}}$

\section{Evaluasi kecukupan proses pasteurisasi}

Perhitungan holding time. Perhitungan kecukupan proses pasteurisasi dalam sistem kontiyu ditentukan oleh holding time $(\mathrm{t})$ dari fluida yang paling cepat bergerak dalam pipa (Morison et al. 2013). Dengan menggunakan persamaan gerak lurus beraturan untuk menghitung waktu tempuh sebagaimana persamaan $4 \mathrm{a}$, holding time dapat dihitung dengan menggunakan persamaaan $4 \mathrm{~b}$, dimana $\mathrm{S}(\mathrm{m})$ merupakan jarak tempuh dapat diasumsikan dengan panjang pipa L (m). Dengan demikian holding time (detik) dihitung berdasarkan pada panjang pipa $(\mathrm{L}, \mathrm{m})$ dan kecepatan maksimum $\left(\mathrm{v}_{\max }, \mathrm{m} /\right.$ detik).

Waktu tempuh $(\mathrm{t}, \operatorname{detik})=\frac{\operatorname{Jarak}(\mathrm{S})}{\operatorname{Kecepatan}(\mathrm{m} / \mathrm{s})}$

Holding time $(\mathrm{t}$, detik $)=\frac{\mathrm{L}}{\mathrm{v}_{\max }}$

Nilai $\mathrm{V}_{\max }$ dipengaruhi oleh sifat fluida dan model aliran fluida di dalam pipa. Sifat fluida yang berpengaruh adalah viskositas, nilai $\mathrm{n}$ dan nilai $\mathrm{K}$, sedangkan model aliran fluida di dalam pipa dapat bersifat laminar atau turbulen. Model aliran laminar atau turbulen dihitung dengan menggunakan bilangan Reynold (Re) (persamaan 5), dimana Re kurang dari 2100 menunjukan aliran laminar, sedangkan Re lebih dari 2100 menunjukan aliran turbulen. Nilai $\rho$ adalah densitas fluida $(\mathrm{g} / \mathrm{mL}), \mathrm{D}$ adalah diameter pipa (m), $\bar{v}$ adalah kecepatan rata-rata (m/detik) dan $\mu$ adalah viskositas fluida (cP). Untuk fluida nonNewtonian, Re dihitung dengan persamaan (6) dimana $\mathrm{R}$ adalah jari-jari pipa (m).

$\operatorname{Re}=\frac{\rho D \bar{v})}{\mu}$

$\operatorname{Re}=\quad \begin{gathered}8(\bar{v})^{2-\mathrm{n}}(\mathrm{R})^{\mathrm{n}} \rho \\ \mathrm{K}\left[\frac{3 n+1}{n}\right]^{\mathrm{n}}\end{gathered}$

Nilai $\mathrm{v}_{\max }$ dihitung dari kecepatan rata-rata (persamaan (7)) dan dengan mempertimbangkan jenis fluida dan sifat aliran. Untuk fluida Newtonian dengan aliran laminar, maka kecepatan maksimum fluida dalam pipa dapat dihitung menggunakan persamaan (8), sementara untuk fluida non-Newtonian dengan aliran laminar, kecepatan fluida dapat dihitung menggunakan persamaan 
(9). Holding time dari fluida yang paling cepat bergerak di dalam holding tube dihitung dengan persamaan (4b). Nilai Q menunjukkan debit aliran fluida ( $\mathrm{m}^{3} /$ detik) sedangkan A menunjukkan luas penampang pipas $\left(\mathrm{m}^{2}\right)$. Debit aliran ditentukan berdasarkan debit tertinggi dari empat batch proses.

$\bar{v}=\frac{Q}{A}$

$\mathrm{v}_{\max }=2 \bar{v}$

$\mathrm{v}_{\max }=\frac{3 n+1}{n+1} \bar{v}$

Standar kecukupan proses pasteurisasi. Suhu pasteurisasi $\left(85^{\circ} \mathrm{C}\right.$ dan $\left.95^{\circ} \mathrm{C}\right)$ dihitung nilai lethal ratenya dibandingkan dengan suhu standar $\left(82.2^{\circ} \mathrm{C}\right)$ dengan menggunakan persamaan (10). Nilai pasteurisasi (P) aktual dihitung dengan menggunakan persamaan (11), dimana $\mathrm{t}$ adalah holding time (dari persamaan (4)).

$\mathrm{LR}=10^{\mathrm{T}-\mathrm{Tref} / \mathrm{z}}$

$P=\int_{0}^{x} L R \cdot d t$

Mikroba yang menjadi target proses pasteurisasi, nilai $\mathrm{D}$ dan $\mathrm{z}$ pada suhu referensi, serta nilai $\mathrm{D}$ di suhu $82.2^{\circ} \mathrm{C}$ dapat dilihat pada Tabel 1 . Nilai pasteurisasi (P) hitung pada suhu $82.2^{\circ} \mathrm{C}\left(\mathrm{P}_{82.2}\right)$ untuk berbagai siklus nilai D yang berbeda (2D, 3D dan 6D). Kecukupan proses pasteurisasi dilakukan dengan membandingkan nilai $\mathrm{P}$ pada suhu $85^{\circ} \mathrm{C}$ dan $95^{\circ} \mathrm{C}$ dengan nilai $\mathrm{P}_{82.2}$ untuk masing-masing mikroba. Apabila nilai $\mathrm{P}$ lebih kecil dari nilai $\mathrm{P}_{82.2}$ maka proses pasteurisasi tidak mencukupi untuk membunuh mikroba atau enzim target, sedangkan apabila nilai $\mathrm{P}$ lebih besar dari nilai $\mathrm{P}_{82.2}$ maka proses pasteurisasi mencukupi (Hafzialman et al. 2014).

\section{Evaluasi stabilitas penyimpanan dan umur simpan}

KKM yang diproses pada suhu pasteurisasi yang berbeda dievaluasi stabilitasnya selama penyimpanan dan ditentukan umur simpannya. Analisis dilakukan dengan metode akselerasi model Arrhenius, yaitu dengan menyimpan sampel KKM pada suhu yang lebih tinggi dari suhu penyimpanan normal (Faridah et al. 2013; Loebis dan Junaidi 2013; Rakcejeva et al. 2013; Haryati et al. 2015; Phimolssiripol dan Suppakul 2016). Suhu penyimpanan yang dipilih adalah 35,45 , dan $55^{\circ} \mathrm{C}$. Perubahan mutu produk yang disimpan di masing-masing suhu penyimpanan diamati secara periodik pada hari ke-0, 4, 7, 11, 14, 21, 28 dan 35 hari. Pengamatan yang dilakukan men-cakup nilai viskositas dan warna yang masingmasing dilakukan secara duplo. Viskositas diukur dengan Brookfield viscometer pada kecepatan rotasi $40 \mathrm{rpm}$, sedangkan warna (L, a dan b) diukur dengan Lovibond colorimeter dilakukan dengan mengukur sampel sehingga diperoleh nilai $\mathrm{L}$, a dan $\mathrm{b}$, dimana $\mathrm{L}$ menunjukkan tingkat kecerahan, a menunjukkan intensitas warna merah hingga hijau dan b menunjukkan intensitas warna kuning hingga biru.

Umur simpan. Perhitungan umur simpan dengan model Arrhenius mengacu pada Kusnandar et al. (2010) sebagaimana persamaan (12) dan (13). Nilai konstanta laju reaksi (k) dari perubahan mutu pada masing-masing suhu ditentukan dengan model persamaan ordo nol atau satu, kemudian ditentukan model persamaan Arrheniusnya. Berdasarkan model persamaan Arrhenius tersebut, maka dapat ditentukan nilai $\mathrm{k}$ pada suhu penyimpanan normal sehingga dapat dihitung umur simpannya.

t orde nol $=\frac{(A 0-A)}{k}$

$\mathrm{t}$ orde satu $=\frac{(\ln A 0-\ln A)}{k}$

dimana, $\mathrm{t}=$ prediksi umur simpan (hari); $\mathrm{A}_{0}=$ nilai mutu awal; $\mathrm{A}=$ nilai mutu produk yang tersisa setelah waktu $t$; $\mathrm{k}=$ konstanta penurunan mutu pada suhu normal.

Batas mutu untuk viskositas dan warna ditentukan berdasarkan batas penerimaan secara organoleptik, yaitu penerimaan terhadap kekentalan untuk menentukan batas mutu viskositas dan penerimaan terhadap warna untuk penentuan batas mutu warna. Mutu organoleptik diamati oleh 10 orang panelis terlatih dengan menggunakan uji penerimaan dengan skala nilai 1-7 untuk masing-masing atribut. Untuk atribut warna dan penerimaan keseluruhan, nilai skor 1 menunjukan sangat tidak suka dan nilai skor 7 menunjukan sangat suka. Adapun untuk atribut ketengikan, nilai skor 1 menunjukan sangat tidak tengik, dan nilai skor 7 menunjukan sangat tengik. Batas penerimaan secara sensori ditentukan saat nilai skor penerimaan keseluruhan panelis mulai menunjukan tingkat ketidaksukaan terhadap KKM (nilai<4). Umur simpan KKM ditentukan pada suhu distribusi $\left(32^{\circ} \mathrm{C}\right)$.

Tabel 1. Nilai $D$ dan Z dari mikroba dan enzim target untuk mengevaluasi kecukupan proses pasteurisasi KKM

\begin{tabular}{|c|c|c|c|c|c|c|c|}
\hline \multirow{2}{*}{ Target } & \multirow{2}{*}{ Suhu Ref $\left({ }^{\circ} \mathrm{C}\right)$} & \multirow{2}{*}{ Nilai Z $\left({ }^{\circ} \mathrm{C}\right)$} & \multirow{2}{*}{ D (menit) } & \multicolumn{4}{|c|}{ Nilai Pasteurisasi $\left(\mathbf{P}_{82.2}\right.$, menit) } \\
\hline & & & & $D_{82.2}$ (menit) & $2 \mathrm{D}_{82.2}$ & $3 \mathrm{D}_{82.2}$ & $6 \mathrm{D}_{82.2}$ \\
\hline Sel vegetatif, kapang, khamir ${ }^{1}$ & 65.5 & 3.7 & 3 & 0.00009 & 0.00018 & 0.00027 & 0.00054 \\
\hline Salmonella $s p p^{2}$ & 68.3 & 5 & 0.01 & 0.0003 & 0.0006 & 0.0009 & 0.0017 \\
\hline$L$ monocytogenes & 68.9 & 6.8 & 0.1 & 0.0011 & 0.0022 & 0.0033 & 0.0066 \\
\hline Staphylococcus spp ${ }^{3}$ & 60 & 9 & 6 & 0.0205 & 0.0410 & 0.0615 & 0.1229 \\
\hline Lipase $^{4}$ & 140 & 38.9 & 2 & 61.2917 & 122.4394 & 183.6591 & 367.3182 \\
\hline
\end{tabular}

Keterangan: ${ }^{1}$ Toledo (2007), ${ }^{2}$ Fernandes (2008), ${ }^{3}$ Necidova et al. $(2016),{ }^{4}$ Anderson et al. (1979) 


\section{HASIL DAN PEMBAHASAN}

\section{Pemenuhan persyaratan}

Tabel 2 menunjukan hasil analisis fisika kimia, kandungan lemak susu memenuhi batas minimal yang dipersyaratkan dalam Kategori Pangan (nomor 01.3.1) (BPOM 2015). Adapun hasil analisis mikrobiologi sampel susu yang diformulasi sebelum dan setelah proses pasteurisasi dapat dilihat pada Tabel 3. Angka lempeng total, koliform, kapang khamir, Staphilococcus aureus, Salmonella, dan Lysteria menunjukkan hasil yang rendah. Dengan demikian, kandungan mikroba dari KKM telah memenuhi persyaratan batas maksimum cemaran mikrobiologi untuk pangan olahan (BPOM 2016).

Tabel 2. Komposisi fisik dan kimia KKM

\begin{tabular}{lc}
\hline \multicolumn{1}{c}{ Komponen } & $(\%)$ \\
\hline Air $(\% b b)$ & $28.00 \pm 0.11$ \\
Lemak (\%bb) & $10.13 \pm 0.12$ \\
Protein (\%bb) & $2.23 \pm 0.06$ \\
Sukrosa (\%bb) & $47.63 \pm 0.21$ \\
Total padatan $(\% \mathrm{bb})$ & $72.00 \pm 0.30$ \\
Densitas $\left(\mathrm{g} / \mathrm{cm}^{3}\right)$ & $1.282 \pm 0.00$ \\
$\mathrm{pH}$ & $5.96 \pm 0.02$ \\
\hline
\end{tabular}

Tabel 3. Kandungan mikroba KKM sebelum dan setelah pasteurisasi

\begin{tabular}{|c|c|c|c|}
\hline Parameter & $\begin{array}{c}\text { Sebelum } \\
\text { Pasteurisasi }\end{array}$ & $\begin{array}{c}\text { Setelah } \\
\text { Pasteurisasi }\end{array}$ & Standar \\
\hline ALT (koloni/g) & $1000-5000$ & $<100$ & $\begin{array}{l}\text { SNI } \\
2897: 2008\end{array}$ \\
\hline $\begin{array}{l}\text { Koliform } \\
\text { (koloni /g) }\end{array}$ & $<10$ & $<10$ & $\begin{array}{l}\text { BS ISO } \\
4832: 2006\end{array}$ \\
\hline $\begin{array}{l}\text { Kapang } \\
\text { (koloni /g) }\end{array}$ & $<10$ & $<10$ & $\begin{array}{l}\text { SNI 19- } \\
2897: 1992\end{array}$ \\
\hline $\begin{array}{l}\text { Khamir } \\
\text { (koloni /g) }\end{array}$ & $<10$ & $<10$ & \\
\hline $\begin{array}{l}S \text { aureus } \\
\text { (koloni /g) }\end{array}$ & $<10$ & $<10$ & $\begin{array}{l}\text { SNI ISO } \\
6888: 2012\end{array}$ \\
\hline $\begin{array}{l}\text { Salmonella } \\
\text { (Negatif / } 25 \mathrm{~g} \text { ) }\end{array}$ & Negatif & Negatif & $\begin{array}{l}\text { SNI ISO } \\
6579: 2015\end{array}$ \\
\hline
\end{tabular}

\section{Sifat reologi}

Hasil pengukuran viskositas pada berbagai kecepatan rotasi menunjukkan sampel susu sebelum proses pasteurisasi memiliki nilai viskositas yang cenderung menurun dengan meningkatnya kecepatan rotasi (Gambar 1). Hal ini menunjukkan susu yang diformulasi cenderung bersifat pseudoplastik. Hasil ini sejalan dengan yang dilaporkan oleh Bienvenue et al. (2003) dan Karlsson et al. (2005). Hasil pengukuran shear rate dan sear stress (Tabel 4) dan plot hubungan antara shear rate dan shear stress menunjukkan ketergantungan nilai shear stress terhadap shear rate, yaitu diperoleh persamaan Power Law, yaitu $\tau=0.77 \gamma^{0.91}$. Dari persamaan ini dapat diketahui nilai $\mathrm{n}$ dan $\mathrm{K}$ secara berturut-turut adalah 0.91 dan 0.77 dyne.detik $/ \mathrm{cm}^{2}$. Nilai $\mathrm{n}$ dari sampel memiliki nilai $\mathrm{n}$ di bawah 1, sehingga susu yang telah diformulasi dikategorikan fluida jenis non-Newtonian pseudoplastik (Toledo 2007). Proses penguapan dan penambahan laktosa terhadap susu setelah pasteurisasi dapat menurunkan nilai $\mathrm{n}$ dan meningkatkan nilai $\mathrm{K}$, namun dalam hal ini perhitungan sifat aliran fluida dalam holding tube berdasarkan pada susu sebelum proses tersebut. Morison et al. (2013) menunjukkan bahwa KKM dengan konsentrasi total padatan di atas 30\% bersifat pseudoplastik.

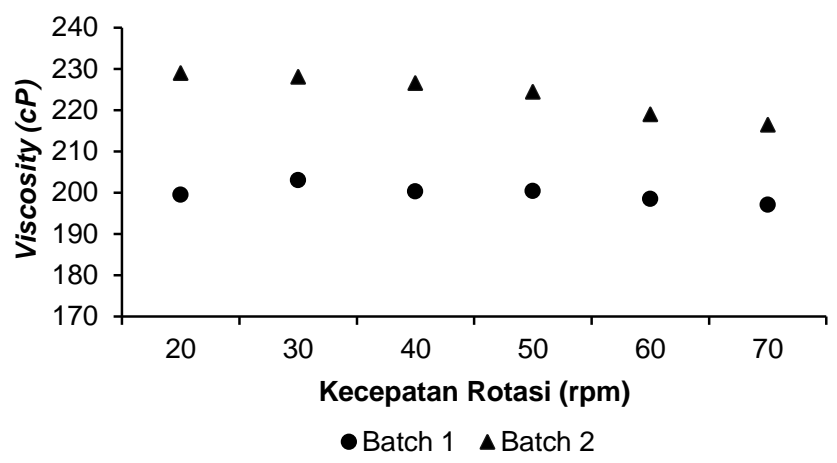

Gambar 1. Viskositas krimer kental manis yang diukur pada beberapa kecepatan rotasi

\section{Kecukupan proses pasteurisasi}

Debit aliran dan kecepatan susu yang diformulasi mengalir di dalam holding tube dapat dilihat pada Tabel 5 , yaitu minimal $7130 \mathrm{~kg} / \mathrm{jam}\left(0.0019 \mathrm{~m}^{3} /\right.$ detik $)$ dan maksimal $7175 \mathrm{~kg} / \mathrm{jam}\left(0.0020 \mathrm{~m}^{3} /\right.$ detik$)$. Kecukupan proses pasteurisasi ditentukan berdasarkan holding time (waktu tinggal) yang paling pendek pada holding tube, sehingga dipilih debit maksimal. Dengan menggunakan persamaan (7), maka kecepatan rata-rata bahan $(\bar{v})$ dari debit maksimal adalah $0.69 \mathrm{~m} /$ detik.

Karena bahan yang masuk ke dalam holding tube bersifat non-Newtonian, maka perhitungan bilangan Reynold (Re) menggunakan persamaan (6) dan diperoleh bilangan Re sebesar 891.92. Toledo (2007) menyatakan bahwa fluida yang memiliki bilangan Re kurang dari 2100 dikelompokkan sebagai aliran laminar. Fluida Newtonian yang mengalir secara laminar memiliki kecepatan maksimum $\left(\mathrm{v}_{\max }\right)$ dua kali dari kecepatan rataratanya $(\bar{v})$. Dengan menggunakan persamaan (8), maka kecepatan maksimum $\left(\mathrm{v}_{\max }\right)$ adalah $1.39 \mathrm{~m} /$ detik. Dari persamaan (9), maka holding time adalah 16.66 detik atau 0.27 menit. Nilai pasteurisasi untuk suhu pasteurisasi $85^{\circ} \mathrm{C}$ dan $95^{\circ} \mathrm{C}$ untuk jenis mikroba yang berbeda disajikan pada Tabel 6 .

Tabel 4. Nilai viskositas dan torque pada berbagai kecepatan rotasi, dan nilai shear rate dan shear stress yang diperoleh

\begin{tabular}{ccccccc}
\hline $\begin{array}{c}\text { Speed Rotasi (N) } \\
(\mathbf{r p m})\end{array}$ & \% Torque & Suhu $\left({ }^{\circ} \mathbf{C}\right)$ & Viscosity (cP) & Torque (A) & $\begin{array}{c}\text { Shear Rate } \\
(\mathbf{1} / \mathbf{d e t i k})\end{array}$ & $\begin{array}{c}\text { Shear Stress } \\
\left(\mathbf{d y n e}^{\mathbf{c}} \mathbf{\mathbf { c m } ^ { 2 } )}\right.\end{array}$ \\
\hline 20 & 12 & 42.6 & 229 & 109.813 & 29.25 & 30.79 \\
30 & 17.8 & 42.0 & 228 & 153.604 & 40.91 & 46.19 \\
40 & 22.8 & 39.0 & 226.5 & 203.457 & 54.19 & 61.58 \\
50 & 28.3 & 38.4 & 224.4 & 251.964 & 67.11 & 76.98 \\
60 & 33.5 & 38.5 & 219 & 295.081 & 78.59 & 92.37 \\
70 & 39.2 & 38.7 & 216.4 & 340.219 & 90.61 & 107.77 \\
\hline
\end{tabular}


Nilai pasteurisasi untuk sel vegetatif, khamir, kapang, Salmonella, Staphylococcus, dan Lysteria monocytogenes baik pada suhu $85^{\circ} \mathrm{C}$ dan $95^{\circ} \mathrm{C}$ lebih besar dari nilai pasteurisasi target (3D dan 6D), yaitu yaitu minimal 0.57 menit untuk suhu $85^{\circ} \mathrm{C}$ dan 7.34 menit untuk suhu suhu $95^{\circ} \mathrm{C}$. Namun demikian, proses pemanasan tidak cukup untuk menurunkan enzim lipase, dimana pada suhu yang dipilih hanya memberikan nilai pasteurisasi sebesar sebesar 0.33 menit untuk suhu suhu $85^{\circ} \mathrm{C}$ dan 0.59 menit untuk suhu suhu $95^{\circ} \mathrm{C}$. Hal ini karena enzim lipase cukup tahan panas, yaitu dengan nilai $\mathrm{D}_{140}$ sebesar 2 menit dan nilai $\mathrm{Z}$ sebesar $38.9^{\circ} \mathrm{C}$ sebagaimana dapat dilihat pada Tabel (1) (Anderson et al. 1979).

Tabel 5. Debit aliran krimer kental manis dalam pipa

\begin{tabular}{ccc}
\hline Batch & Debit Aliran (kg/jam) & Kecepatan (m/detik) \\
\hline 1 & 7130 & 0.6886 \\
2 & 7154 & 0.6909 \\
3 & 7140 & 0.6896 \\
4 & 7175 & 0.6930 \\
\hline
\end{tabular}

Tabel 6. Nilai Pasteurisasi pada suhu $85^{\circ} \mathrm{C}$ dan $95^{\circ} \mathrm{C}$ untuk target mikroorganisme dan enzim lipase

\begin{tabular}{lccc}
\hline \multirow{2}{*}{ Target } & $\begin{array}{c}\text { Nilai } \mathbf{Z} \\
\left({ }^{\circ} \mathbf{C}\right)\end{array}$ & \multicolumn{2}{c}{$\begin{array}{c}\text { Nilai Pasteurisasi } \\
\text { (menit) }\end{array}$} \\
\cline { 3 - 4 } & 3.7 & $\mathbf{P}_{85}$ & $\mathbf{P}_{95}$ \\
\hline Sel vegetatif, kapang, & & & 799.80 \\
khamir & & & \\
Salmonella spp & 5.0 & 1.01 & 100.82 \\
Staphylococcus spp & 9.0 & 0.57 & 7.34 \\
L monocytogenes & 6.8 & 0.72 & 21.18 \\
Lipase & 38.9 & 0.33 & 0.59 \\
\hline
\end{tabular}

Keberadaan enzim lipase berpengaruh terhadap penurunan mutu KKM selama penyimpanan, karena lipase dapat menyebabkan reaksi oksidasi asam lemak yang berkontribusi pada pembentukan bau tengik secara berangsur-angsur pada KKM selama penyimpanan.
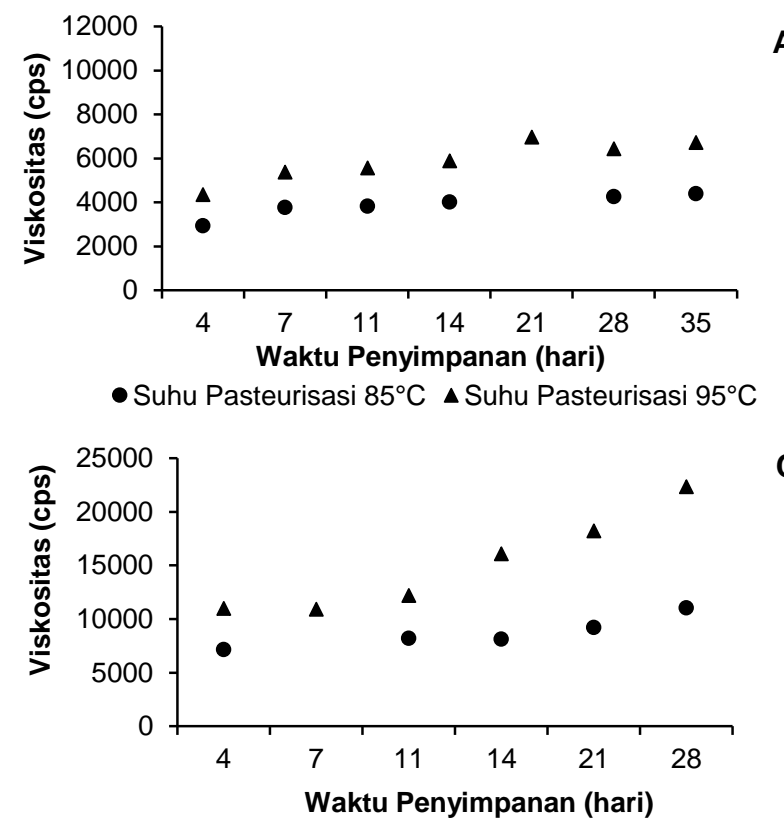

- Suhu Pasteurisasi $85^{\circ} \mathrm{C}$ \ Suhu Pasteurisasi $95^{\circ} \mathrm{C}$
Menurut Walstra et al. (2006) enzim lipolitik umumnya menyerang posisi 1 dan 3 dari trigliserida sehingga menghasilkan asam lemak bebas yang bersifat volatil. Inaktivasi lipase yang lebih besar dapat dilakukan dengan meningkatkan suhu proses pasteurisasi (Hetrick dan Tracy 1948) atau dengan meningkatkan waktu pasteurisasi (Vercet et al. 1997), dengan mempertimbangkan penerimaan sensori dan umur simpan.

\section{Stabilitas dan umur simpan KKM}

Selain faktor keamanan pangan, mutu KKM penting diperhatikan untuk melihat penerimaan konsumen tarhadap produk tersebut. Atribut mutu yang umumnya digunakan sebagai parameter kerusakan adalah perubahan nilai viskositas (Kalyankar et al. 2016). Viskositas KKM disebabkan oleh kandungan total padatan yang tinggi, di samping juga adanya penambahan pati sebagai bahan pengental. Secara umum viskositas meningkat terhadap lama waktu penyimpanan (Gambar 2). Mengacu kepada Bienvenue et al. (2003) kenaikan viskositas selama penyimpanan disebabkan oleh adanya penyatuan kembali struktur tiga dimensi selama penyimpanan, menghasilkan kontak yang lebih besar antara partikel terdispersi yang meningkatkan viskositas. Adapun menurut Saragih (2011) kenaikan viskositas KKM dapat terjadi karena adanya retrogradasi molekul pati, yaitu terjadinya re-asosiasi amilosa dan amilopektin melalui ikatan hidrogen yang terjadi secara perlahan-lahan selama penyimpanan. Secara umum, warna KKM yang dinyatakan dengan nilai $\mathrm{L}$, a dan $\mathrm{b}$ mengalami perubahan selama penyimpanan. Tingkat kecerahan (nilai L) cenderung menurun (Gambar 3), pembentukan warna kemerahan dan kuning (nilai b) meningkat (Gambar 4).

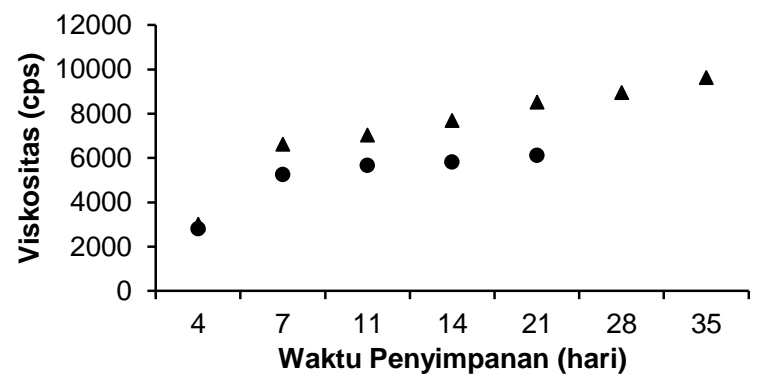

- Suhu Pasteurisasi $85^{\circ} \mathrm{C}$ ॥ Suhu Pasteurisasi $95^{\circ} \mathrm{C}$

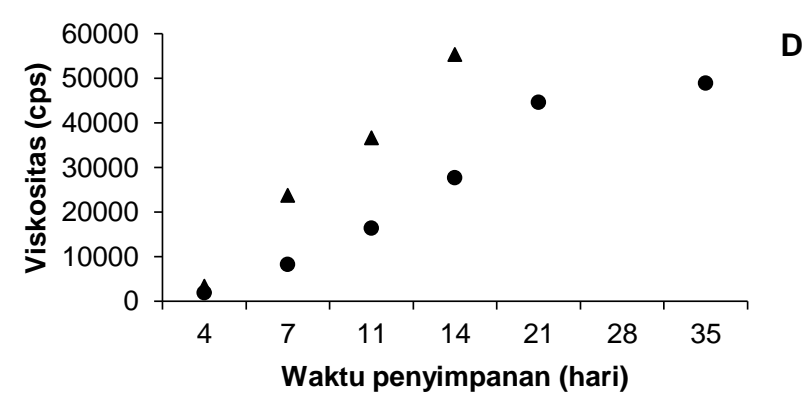

- Suhu Pasteurisasi $85^{\circ} \mathrm{C}$ \ Suhu Pasteurisasi $95^{\circ} \mathrm{C}$

Gambar 2. Perubahan viskositas KKM selama penyimpanan pada suhu $27^{\circ} \mathrm{C}$ (a), $35^{\circ} \mathrm{C}$ (b), $45^{\circ} \mathrm{C}$ (c) dan $55^{\circ} \mathrm{C}$ (d) 

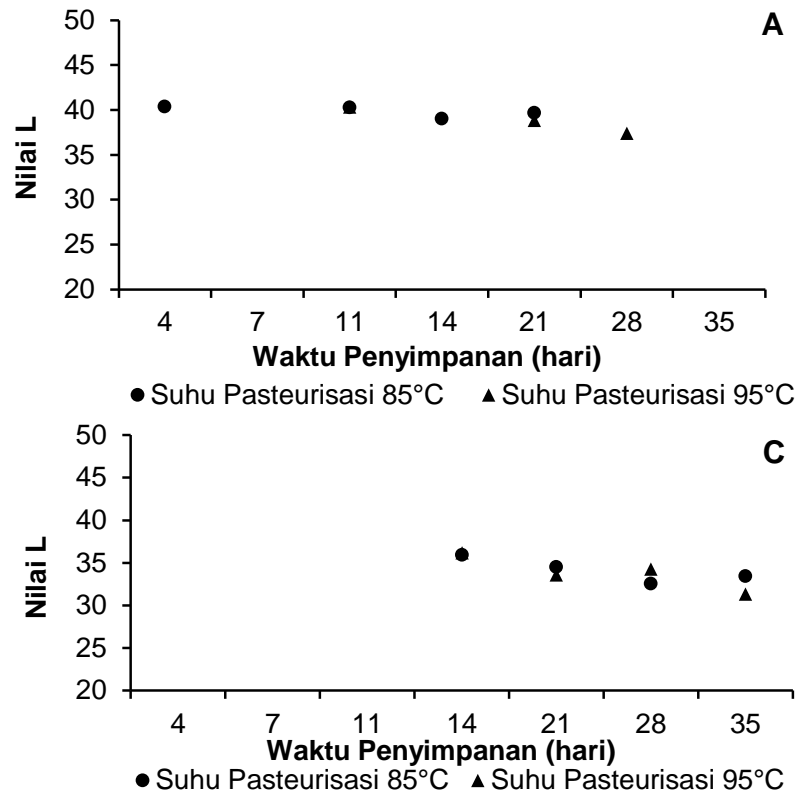

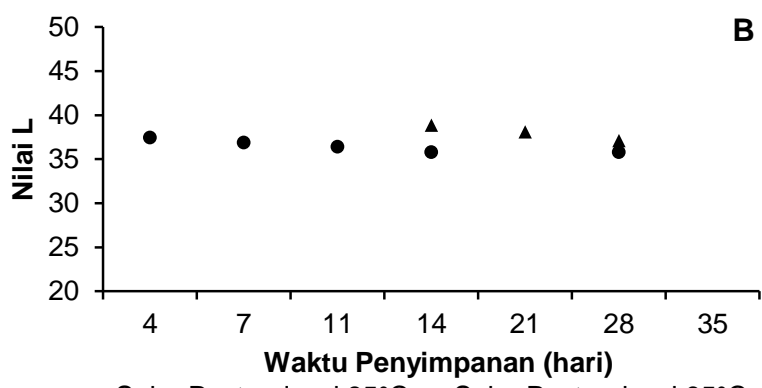

- Suhu Pasteurisasi $85^{\circ} \mathrm{C}$ ॥ Suhu Pasteurisasi $95^{\circ} \mathrm{C}$

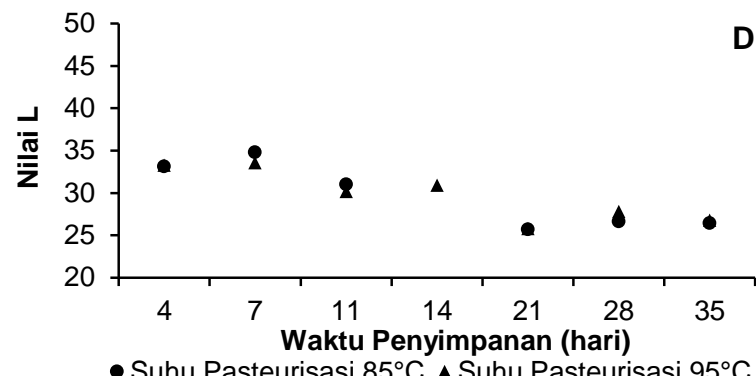

Gambar 3. Perubahan intensitas nilai L KKM selama penyimpanan pada suhu $27^{\circ} \mathrm{C}(\mathrm{A}), 35^{\circ} \mathrm{C}(\mathrm{B}), 45^{\circ} \mathrm{C}(2 \mathrm{C})$ dan $55^{\circ} \mathrm{C}(\mathrm{D})$
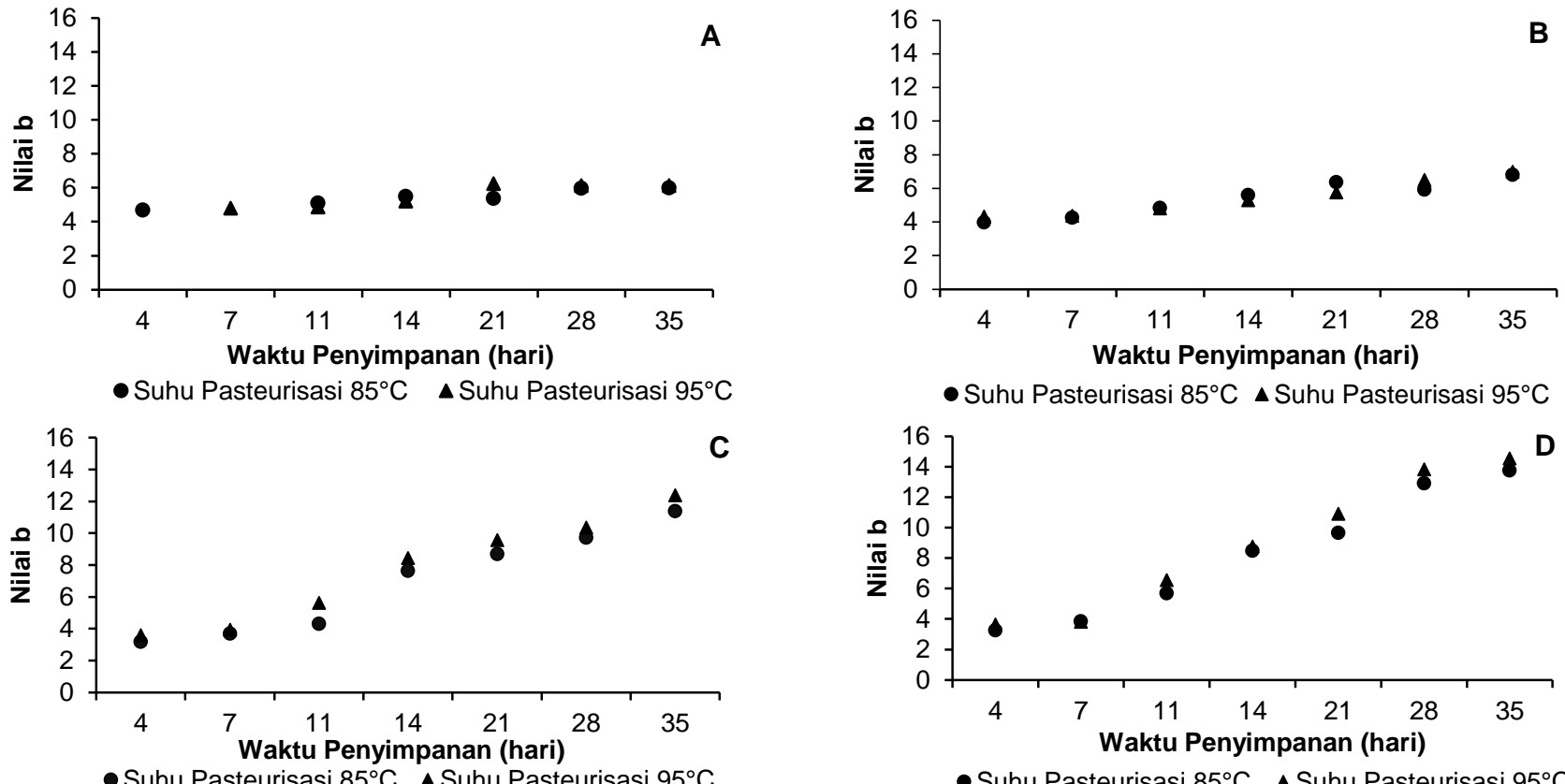

- Suhu Pasteurisasi $85^{\circ} \mathrm{C}$ ॥ Suhu Pasteurisasi $95^{\circ} \mathrm{C}$

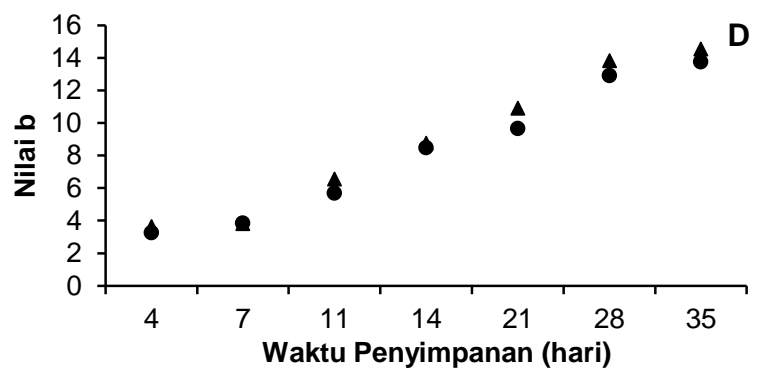

- Suhu Pasteurisasi $85^{\circ} \mathrm{C}$ ॥ Suhu Pasteurisasi $95^{\circ} \mathrm{C}$

Gambar 4. Perubahan intensitas nilai b KKM selama penyimpanan pada suhu $27^{\circ} \mathrm{C}(\mathrm{A}), 35^{\circ} \mathrm{C}(\mathrm{B}), 45^{\circ} \mathrm{C}(\mathrm{C})$ dan $55^{\circ} \mathrm{C}(\mathrm{D})$

Menurut Saragih (2011) nilai b dapat digunakan untuk menentukan parameter mutu KKM. Perubahan warna ini dapat disebabkan oleh reaksi pencoklatan nonenzimatis (reaksi Maillard) yang terjadi akibat adanya reaksi antara gula pereduksi (laktosa) dengan asam amino, peptida atau protein yang ditandai dengan pembentukan warna coklat disertai reaksi samping yang menghasilkan komponen volatil yang berkontribusi pada pembentukan rasa dan aroma (Manzocco et al. 2001). Tabel 7 menunjukkan hasil perhitungan nilai konstanta laju reaksi (k) dari atribut viskositas dan warna (nilai $\mathrm{L}$ dan b) dari KKM pada masing-masing suhu dengan menggunakan pendekatan ordo reaksi nol dan satu.
Berdasarkan nilai koefisien $\mathrm{R}^{2}$-nya, maka laju reaksi untuk viskositas dan warna (nilai L dan b) cenderung mendekati reaksi ordo nol. Dari persamaan yang didapatkan dengan memplotkan nilai $\mathrm{k}$ (sumbu y) dan nilai $1 / \mathrm{T}$ (sumbu x), maka diperoleh model persamaan Arhenius yang digunakan untuk memprediksi nilai $\mathrm{k}$ pada suhu pernyimpanan normal. Nilai kritis atribut mutu pada penelitian ini ditentukan berdasarkan hasil uji organoleptik, yaitu penerimaan secara keseluruhan KKM apabila rata-rata skor yang diberikan panelis terlatih sudah mendekati skor tidak suka. Nilai kritis untuk atribut viskositas dan warna (nilai L dan b) disajikan pada Tabel 8. 
Tabel 7. Nilai konstanta laju reaksi $(k)$ dan $R^{2}$ viskositas dan warna KKM berdasarkan reaksi ordo 0 dan 1

\begin{tabular}{|c|c|c|c|c|c|c|}
\hline \multirow{2}{*}{ Atribut Mutu } & \multirow{2}{*}{ Suhu Pasteurisasi $\left({ }^{\circ} \mathrm{C}\right)$} & \multirow{2}{*}{ Suhu Penyimpanan $\left({ }^{\circ} \mathrm{C}\right)$} & \multicolumn{2}{|c|}{ Ordo 0} & \multicolumn{2}{|c|}{ Ordo 1} \\
\hline & & & $\mathbf{k}$ & $\mathbf{R}^{2}$ & $\mathbf{k}$ & $\mathbf{R}^{2}$ \\
\hline \multirow[t]{8}{*}{ Viskositas } & 85 & 27 & 201.9 & 0.8090 & 0.0540 & 0.7590 \\
\hline & & 35 & 720.0 & 0.7220 & 0.1660 & 0.6640 \\
\hline & & 45 & 702.8 & 0.8330 & 0.2000 & 0.6830 \\
\hline & & 55 & 8664.0 & 0.9450 & 0.5190 & 0.8180 \\
\hline & 95 & 27 & 380.9 & 0.8240 & 0.0670 & 0.8140 \\
\hline & & 35 & 929.9 & 0.8400 & 0.1520 & 0.7080 \\
\hline & & 45 & 2362.0 & 0.9180 & 0.2620 & 0.7670 \\
\hline & & 55 & 16890.0 & 0.9930 & 0.8820 & 0.8470 \\
\hline \multirow[t]{8}{*}{ NIlai L } & 85 & 27 & 0.2486 & 0.4673 & 0.0062 & 0.4634 \\
\hline & & 35 & 0.3432 & 0.8478 & 0.0094 & 0.8491 \\
\hline & & 45 & 0.9490 & 0.7036 & 0.0276 & 0.6963 \\
\hline & & 55 & 1.4898 & 0.8233 & 0.0500 & 0.8262 \\
\hline & 95 & 27 & 0.9439 & 0.9685 & 0.0242 & 0.9646 \\
\hline & & 35 & 0.8825 & 0.9941 & 0.0232 & 0.9931 \\
\hline & & 45 & 1.3875 & 0.8011 & 0.0412 & 0.7995 \\
\hline & & 55 & 1.2659 & 0.7901 & 0.0424 & 0.7785 \\
\hline \multirow[t]{8}{*}{ Nilai b } & 85 & 27 & 0.2259 & 0.9287 & 0.0423 & 0.9335 \\
\hline & & 35 & 0.4782 & 0.9258 & 0.0912 & 0.9252 \\
\hline & & 45 & 1.4677 & 0.9611 & 0.2312 & 0.9474 \\
\hline & & 55 & 1.9127 & 0.9773 & 0.2600 & 0.9685 \\
\hline & 95 & 27 & 0.3286 & 0.8152 & 0.0601 & 0.8249 \\
\hline & & 35 & 0.4716 & 0.9678 & 0.0862 & 0.9793 \\
\hline & & 45 & 1.5420 & 0.9723 & 0.2207 & 0.9488 \\
\hline & & 55 & 2.0386 & 0.9765 & 0.2590 & 0.9523 \\
\hline
\end{tabular}

Tabel 8. Nilai batas kritis parameter mutu KKM berdasarkan model ordo 0

\begin{tabular}{ccccc}
\hline \multirow{2}{*}{ Suhu } & \multicolumn{2}{c}{ Viskositas (cP) } & \multicolumn{2}{c}{ Warna (L dan b) } \\
\cline { 2 - 5 } & Nilai Awal & $\begin{array}{c}\text { Nilai } \\
\text { Kritis }\end{array}$ & Nilai Awal & Nilai Kritis \\
\hline 85 & 2917.5 & 20000 & 4.68 & 9.57 \\
95 & 4338 & 20000 & 4.79 & 9.57 \\
\hline
\end{tabular}

Umur simpan pada suhu $32^{\circ} \mathrm{C}$ (suhu selama distribusi) berdasarkan atribut mutu viskositas dapat dilihat pada Tabel 9. Umur simpan yang KKM yang dipasteurisasi pada suhu $85^{\circ} \mathrm{C}$ adalah 292.4 hari (10 bulan) lebih lama dibanding $95^{\circ} \mathrm{C} 174.5$ hari (6 bulan) berdasarkan parameter viskositas. Berdasarkan Saragih (2011) umur simpan KKM berdasarkan viskositas dapat mencapai 12 bulan. Perbedaan umur impan pada produk pangan dapat dipengaruhi beberapa faktor antara lain komposisi bahan, $\mathrm{pH}$, dan suhu pengolahan sebagaimana Muir dan Banks (2003), dan fluktuasi suhu penyimpanan sebagaimana Baeza et al. (2007). Adapun berdasarkan parameter warna yaitu nilai $b$, maka diperoleh umur simpan SKM yang diproses pada suhu $85^{\circ} \mathrm{C}$ (43.2 hari) yang lebih lama dibanding yang diproses pada suhu $95^{\circ} \mathrm{C}$ (30.5 hari). Umur simpan dengan menggunakan parameter nilai L memberikan perhitungan umur simpan yang terlalu pendek sehingga tidak dipilih sebagai parameter penentu umur simpan.

Tabel 9. Umur simpan pada suhu distribusi $\left(32^{\circ} \mathrm{C}\right)$ berdasarkan atribut viskositas dan warna (nilai $L$ dan b) (reaksi ordo 0)

\begin{tabular}{clcc}
\hline $\begin{array}{c}\text { Suhu } \\
\text { Pasteurisasi ( }\end{array}$ & Parameter & Nilai k & $\begin{array}{c}\text { Umur Simpan } \\
\text { (hari) }\end{array}$ \\
\hline 85 & Viskositas & 58.4 & 292.4 \\
& Nilai L & 0.1 & 33.5 \\
& Nilai b & 0.1 & 43.2 \\
95 & Viskositas & 89.7 & 174.5 \\
& Nilai L & 0.8 & 5.4 \\
& Nilai b & 0.2 & 30.2 \\
\hline
\end{tabular}

\section{KESIMPULAN}

Proses pasteurisasi KKM pada suhu $85^{\circ} \mathrm{C}$ dan $95^{\circ} \mathrm{C}$ sudah memadai untuk menurunkan jumlah mikroba awal dan menginaktivasi sel vegetatif, kapang, khamir, Salmonella, Staphylococcus, dan Lysteria monocytegenes, serta telah memenuhi persyaratan mikrobiologi yang ditetapkan oleh BPOM untuk KKM. Namun demikian, kedua suhu tersebut belum cukup untuk menginaktivasi enzim lipase yang diduga berkontribusi pada laju penurunan mutu KKM selama penyimpanan. Umur simpan KKM dipengaruhi oleh suhu pasteurisasi, yaitu KKM yang diproses pada suhu $85^{\circ} \mathrm{C}$ memiliki umur simpan yang lebih panjang dibandingkan yang dipasteurisasi pada suhu $95^{\circ} \mathrm{C}$ berdasarkan parameter viskositas.

\section{DAFTAR PUSTAKA}

Anderson RE, Hedlun CB, Jonsson U. 1979. Thermal inactivation of a heat-resistant lipase produced by the psychrotrophic bacterium Pseudomonas fluorescens. J Dairy Sci 62: 361-367. DOI: 10.3168/jds.S00220302(79)83252-X.

Asaduzzaman M. 2007. A study on the quality of sweetened condensed milk available in the local market of Bangladesh. Bangladesh J Sci Ind Res 42(2): 147-156. DOI: 10.3329/bjsir.v42i2.467.

Baeza R, Mielnicki D, Zamora MC, Chirife J. 2007. Effect of environmental daily temperature fluctuations over one year storage on the prediction of nonenzymatic browning in reduced-moisture foods stored at "ambient" temperature. J Food Control 18(12): 1532-1537. DOI: 10.1016/j.foodcont.2006. 12.001 . 
Bienvenue A, Flores RJ, Singh H. 2003. Rheological properties of concentrated skim milk: influence of heat treatment and genetic variants on the changes in viscosity during storage. J Agric Food Chem 51: 6488-6494. DOI: 10.1021/jf034050.

[BPOM RI] Badan Pengawas Obat dan Makanan Republik Indonesia. 2015. Kategori Pangan 01.0 Produk Susu dan Analognya, Kecuali yang Termasuk Kategori 2. Peraturan Kepala Badan POM Nomor 1 Tahun 2015 tentang Kategori Pangan. Jakarta: BPOM RI.

[BPOM RI] Badan Pengawas Obat dan Makanan Republik Indonesia. 2016. Peraturan Kepala Badan POM Nomor 16 Tahun 2016 tentang Kriteria Mikrobiologi dalam Pangan Olahan. Jakarta: BPOM RI.

Brocklehurst TF, Mitchell GA, Pleass W, Smith AC. 1995. The effect of step changes in sucrose concentration on the growth of Salmonella typhimurium LT2. J Appl Bacteriol 78(5): 495-500. DOI: 10.1111/j.1365-2672.1995.tb03091.x.

[CAC] Codex Alimentarius Commision. 2011. Codex Standard for Sweetened Condensed Milks, Codex Stan 282-1971. Rome: CAC

Faridah DN, Yasni S, Suswantinah A, Aryani GW. 2013. Pendugaan umur simpan dengan metode acceleratted shelf life testing pada produk bandrek instan dan sirup buah pala (Myristica fragrans). J Ilmu Pert Indonesia 18(3): 144-153.

Fernandes R. 2008. Pathogen Profile. Editor. Microbiology Handbook Dairy Products, hal 143-154. ISBN: 978-1-905224-62-3.

Hafzialman, Kusnandar F, Purnomo EH. 2014. Evaluasi kecukupan panas proses pasteurisasi Nata de Coco dalam kemasan plastic polietilen. J Mutu Pangan 1(1): 33-39.

Hariyadi P. 2017. Teknologi Proses Termal untuk Industri Pangan. Media Pangan Indonesia, Bogor. ISBN: 978-602-73071-3-1.

Haryati, Estiasih T, Heppy F, Ahmadi K. 2015. Pendugaan umur simpan dengan metode accelerated shelf-life testing (ASLT) dengan pendekatan Arhenius pada produk tape ketan hitam khas Mojokerto hasil sterilisasi. J Pangan Agro Ind 3(1): 156-165.

Heldman DR, Singh RP. 2009. Introduction to Food Engineering. Edisi 4. Academic Press, London. ISBN: 978-0-12-370900-4.

Hetrick JH, Tracy PH. 1948. Effect of high-temperature short-time heat treatments on some properties of milk. II. Inactivation of the lipase enzyme. J Dairy Sci 31(10): 881-887. DOI: $10.3168 /$ jds.S00220302(48)92272-3.

Hudson A, Wong T, Lake R. 2003. Pasteurization of Dairy Product: Times, Temperatures, and Evidences Control of Pathogenes. Institut of Environtmental Science and Research Limited. Hal. 12.

Kalyankar SD, Deshmukh MA, Khedkar CD, Deosarkar SS, Sarode AR. 2016. Condense Milk. Encyclopedia of Food and Health. 891-895. DOI: 10.1016/B978-012-384947-2.00192-6.

Kementan RI. 2017. Statistik Konsumsi Pangan. Jakarta. Karlsson AO, Ipsen R, Schrader K, Ardo Y. 2005. Relationship between physical properties of casein micelles and rheology of skim milk. J Dairy Sci 88:3784-3797. DOI: $10.3168 /$ jds.S0022-0302(05)73 064-2.

Kusnandar F, Adawiyah DR, Fitria M. 2010. Pendugaan umur simpan produk biskuitdengan metode akselerasi berdasarkan pendekatan kadar air kritis. J Teknol Industri Pangan 21(2): 117-122.

Madriz MFS. 2003. Preservation of Food. Encyclopedia of Dairy Science 4766-4772. DOI: 10.1016/B0-12227055-X/00968-8.

Morison KR, Phelan JP, Bloore CG. 2013. Viscosity and non-Newtonian behaviour of concentrated milk and cream. Int J Food Properties 16: 882-894. DOI: 10.10 80/10942912.2011.573113.

Muir DD, Banks JM. 2003. Factors affecting the shelflife of milk and milk products. Dairy Proces 185207. DOI: 10.1533/9781855737075.1.185.

Necidova L, Bogdanovica K, Harustiakova D, Bartova K. 2016. Short communication: Pasteurization as a means of inactivating staphylococcal enterotoxins A, B, and C in milk. J Dairy Sci 9: 8638-8634. DOI: 10.3168/jds.2016-11252

Nieuwenhuijse JA. 2011. Concentrated Dairy Product: Sweetemed Condensed Milk. Encyclopedia of Dairy Science, 869-873. DOI: 10.1016/B978-0-08-1005965.00697-1.

Pereira DBC, Sa JFO, Santos MC, Teodoro VAM, Magalhaes FAR, Perrone IT, Silva PHF. 2017. Characterization of physicochemical composition, microbiology, sensory evaluation and microscopical attributes of sweetened condensed milk. Food Sci Technol, 38: 293-298. DOI: 10.1590/1678-457x. 34416.

Phimolssiripol Y dan Suppakul P. 2016. Techniques in Shelf Life Evaluation of Food Product. Reference Module in Food Science DOI: 10.1016/B978-0-08100596-5.03293-5.

Rakcejeva T, Skorina V, Karklina D, Skudra L. 2013. ASLT method for beer accelerated shelf life determination. Int J Nutr Food Eng 7(2): 117-122.

Saragih F. 2011. Pengembangan Formulasi Krimer Kental Manis dengan Karakteristik Mutu Mendekati Susu Kental Manis Skal Pilot Plant dan Factory Trial. [Tesis]. Bogor. Sekolah Pascasarjan, Institut Pertanian Bogor.

Shah MK, Asa G, Sherwood J, Graber K, Berghoz TM. 2017. Eficacy of vacuum pasteurization for inactivation of Salmonella PT 30, E. coli O157:H7 dan Enterococcus facium on low moisture foods. Int Food Microbiol 244(6): 111-118. DOI: 10.1016/ j.ijfoodmicro.2017.01.003.

Silva FPM, Gibs PA. 2010. Non proteolitic Clostridium botulinum spores in low-acid cold-distributed foods and design of pasteurization process. Trends Food 
Sci Technol 21: 95-105. DOI: 10.1016/j.tifs.2009.10. 011.

Sobral MMC, Nunes C, Maia A, Ferreira P, Coimbra MA. 2016. Condition for producing long shelflife fruit salads processed using mild pasteurization. LWT-Food Sci Technol 85(Part B): 316-323. DOI: 10.1016/j.lwt.2016.11.055.

Toledo R. 2007. Fundamentals of Food Processing Engineering. Springer, Georgia. ISBN 978-038729019-5.

Tomasula PM, Kozempel MF. 2004. Flow characteristic of a pilot scale high temperature short time pasteurizer. J Dairy Sci 87(9): 2761-2768. DOI: 10.3168/jds.S0022-0302(04)73403-7.

Vegara S, Marti N, Mena P, Saura D, Valero M. 2013. Effect of pasteurization process and storage on color and shelf life of pomegranate juices. Food Sci Technol 54: 592-596. DOI: 10.1016/j.lwt.2013 .06 .022 .
Vercet A, Lopez P, Burgos J. 1997. Inactivation of heat resistant lipase and protease from Pseudomonas fluorescens by manothermosonication. J Dairy Sci 80: 29-36. DOI: 10.3168/jds.S0022-0302(97)759095.

Vervoort L, Plancken IVD, Grauwet T, Timmermans RAH, Mastwijk HC, Matser AM, Hendrickx ME, Loey AV. 2011. Comparing equivalent thermal, high pressure and pulsed electricfield processes for mild pasteurization of orange juice Part II: Impact on specific chemical and biochemical quality parameters. Innov Food Sci Emerging Technol 12: 466477. DOI: 10.1016/j.ifset.2011.06.003.

Walstra P, Wouters JTM, Geurts TJ. 2006. Milk Components, editor. Dairy Science and Technology, hal 37-62. ISBN: 978-0-8247-2763-5.

JMP-07-19-18-Naskah diterima untuk ditelaah pada 12 Juli 2019 Revisi makalah disetujui untuk dipublikasi pada 31 Oktober 2019. Versi Online: http://journal.ipb.ac.id/index.php/jmpi 